https://doi.org/10.35339/msz.2019.83.02.05

УДК 61.89:615.851:616-07

\author{
А.О. Камінська, Н.К. Агішева *
}

Вінницький національний медичний університет ім. М.І. Пирогова *Харківська медична академія післядипломної освіти

\title{
ЧИННИКИ ПСИХОСОЦІАЛЬНОГО РЕСУРСУ І ЇХНЄ ЗНАЧЕННЯ У ФУНКЦІОНУВАННІ СІМ'Ї, ДЕ ПРОЖИВАЄ ХВОРИЙ 3 ЕНДОГЕННИМ ПСИХІЧНИМ РОЗЛАДОМ
}

\begin{abstract}
Обстежено 168 референтних родичів хворих на параноїдну шизофренію та 75 референтних родичів пацієнтів з афективними розладами (біполярним афективним та рекурентним депресивним розладами), у яких визначали рівні сімейного навантаження та сімейної тривоги в контексті психосоціального функціонування обстежених. Групу контролю становили 55 психічно здорових осіб. Ступінь навантаження на сім'ю встановлювали за допомогою шкали оцінювання навантаження на сім'ю за G. Szmukler et al. (1994), рівень сімейної тривоги - за опитувальником «Аналіз сімейної тривоги» Е.Г. Ейдеміллера та В. Юстіцкіса. Виявлено, що високі рівні сімейної тривоги в референтних родичів пацієнтів з параноїдною шизофренією та афективними розладами зберігаються за тривалості хвороби до 4 років і від 5 до 8 років, після чого показники знижуються до значень, які незначно відрізняються від даних контрольної групи. Це, імовірно, указує на поступове дистанціювання від актуальної сімейної ситуації з переключенням на інші сфери життя. Зі збільшенням тривалості захворювання рівень сімейного навантаження зростає за субшкалою негативних оцінок з одночасним зниженням за субшкалою позитивних оцінок, що відображає зосередженість членів сім’ї на негативних аспектах захворювання. Урахування даних закономірностей $\epsilon$ необхідним при розробці відповідної комплексної системи медико-психологічного супроводу сімей, де проживають пацієнти з ендогенними психічними розладами.

Ключові слова: сімейна тривога, тип ставлення до психічного захворювання, психоемоційна сфера, референтні родичі, ендогенні психічні розлади.
\end{abstract}

\section{Вступ}

Ендогенні психічні розлади (ЕПР) є однією 3 найбільш актуальних проблем охорони здоров'я не тільки для пацієнтів із психічними розладами, а і для членів їхніх сімей $[1,2]$. Як і в багатьох країнах, в Україні референтні родичі стикаються 3 відповідальністю, до якої вони зазвичай не готові. Це вимагає максимального залучення особистісних адаптаційних ресурсів усіх членів сім’ї й активізації психосоціального ресурсу сім’ї в цілому як се- редовища, де проживає хворий з ЕПР, для забезпечення його ресоціалізації та реадаптації.

3 розвитком системи охорони здоров' я референтні родичі стають основними донорами соціальної підтримки для пацієнтів з ЕПР. У ситуації розвитку і прогресування психічного розладу у близького члена сім’ї вони повинні надавати турботу, допомогу та підтримку, витримуючи відповідні наслідки хвороби й лікування. Вплив наявності у сім’ї пацієнта 3 психічним розладом на референтних родичів, ви-

(C) А.О. Камінська, Н.К. Агішева, 2019 
світлений у багатьох дослідженнях [3-5], викликає так званий феномен сімейного навантаження $[6,7]:$ зміни якості життя, обмеження соціальних ролей та діяльності, а також збільшення кількості психосоматичних, тривожних або депресивних симптомів.

Об'єктивними негативними проявами сімейного навантаження $€$ погіршення фізичного здоров'я та якості життя референтних родичів, порушення сімейної взаємодії та збільшення фінансових витрат, тоді як суб'єктивні ефекти пов'язані зі специфічними психоемоційними наслідками: почуттями ізоляції, втрати, тривоги, фрустрації тощо [8, 9]. Відомо, що члени сім'ї, які проживають спільно з пацієнтом або проводять 3 ним тривалий час, зазнають інтенсивнішого сімейного навантаження, адже для тривалого контакту з пацієнтом необхідні увага, доступність, терпіння та психологічна резильєнтність. Водночас негативні наслідки сімейного навантаження й негативний досвід взаємодії з хворим можуть вплинути на здатність референтних родичів до надання підтримки хворому.

Iз сімейним навантаженням пов' язаний i феномен загального підвищення сімейної тривоги, тобто стану підвищеної тривожності в одного або декількох членів сім’ї, нерідко погано усвідомлюваного й недостатньо локалізованого за причиною виникнення [10]. Даний тип тривоги характеризується тим, що виявляється в сумнівах, страхах, побоюваннях, які стосуються сімейного життя - здоров'я членів сім’ї, їхніх поїздок і пізніх повернень, сутичок і конфліктів, що виникають у внутрішньосімейній взаємодії. Тривога ця зазвичай не поширюється на сфери позасімейного функціонування - виробничу діяльність, дружні, сусідські відносини і т. д.

В основі сімейної тривоги, як правило, лежить недостатньо усвідомлювана непевність індивіда у важливому для нього аспекті сімейного життя (невпевненість у почуттях партнеpa, у собі тощо). Індивід витісняє почуття, які можуть проявитись у сімейних відносинах і не вписуються в його уявлення про себе. Сімейна тривога зазвичай виявляється опосередковано і часто - по-різному в усіх членів сім’ї.

Невід'ємними складовими сімейної тривоги є почуття безпорадності й нездатності втрутитися в хід подій у родині, направити його в потрібне русло, що є особливо актуаль- ним у сім'ях пацієнтів з ЕПР. Індивід із сімейно-зумовленою тривогою не відчуває себе значущою дійовою особою в родині, незалежно від того, яку позицію він у ній займає і наскільки активну роль відіграє в дійсності [11-13].

Специфічною особливістю психосоціальної терапії і психосоціальної реабілітації хворих з ЕПР $є$ активне залучення референтних родичів до лікувально-реабілітаційного процесу 3 метою досягнення й утримання максимально високого рівня соціального функціонування пацієнта. Сімейне навантаження й сімейна тривога $є$ чинниками, що визначають психосоціальний ресурс сім'ї та ії потенціал з точки зору забезпечення оптимальних умов для сприяння психосоціальній реабілітації та реадаптації пацієнтів з ЕПР.

Проведено невелику кількість наукових досліджень у цьому напрямку в Україні, однак комплексні системи медико-психологічного супроводу для сімей, де проживають пацієнти з ЕПР, відсутні.

Метою нашого дослідження $\epsilon$ визначення рівня сімейного навантаження й сімейної тривоги в референтних родичів пацієнтів з ЕПР в контексті їхнього психосоціального функціонування для оцінювання психосоціального ресурсу й соціально-терапевтичного потенціалу сім'ї та подальшої розробки відповідної комплексної системи медико-психологічного супроводу сімей, де проживають пацієнти з ЕПР.

\section{Матеріал і методи}

Iз дотриманням принципів біоетики й медичної деонтології та за умови інформованої згоди обстежено 243 референтні родичі хворих на параноїдну шизофренію (168 осіб, РРПШ) та афективні розлади - біполярний афективний і рекурентний депресивний (75 осіб, РРАФР). Критеріями залучення респондентів до участі в дослідженні були: інформована згода на проведення анкетування, клініко-психологічного, психодіагностичного обстеження, відсутність попередніх звернень по допомогу до лікаря-психіатра чи лікаря-нарколога, відсутність черепно-мозкових травм в анамнезі, 1-2-й ступені спорідненості з хворим. До групи РРПШ увійшли 49 дружин і 25 чоловіків хворих, 94 особи, що $є$ одним із батьків пацієнтів із параноїдною шизофренією. До групи РРАФР було залучено 20 дружин і 25 чоловіків хворих, 30 осіб, що є одним із батьків пацієнтів 
з афективними розладами. Обстежені були у віковому діапазоні від 26 до 63 років, середній вік дружин становив $(37,5 \pm 0,8)$ року, чоловіків $(42,3 \pm 0,90)$ року та одного з батьків - $(60,3 \pm 3,7)$ року. До контрольної групи (КГ) увійшли 55 психічно здорових осіб (35 осіб жіночої та 20 осіб чоловічої статі), у сім'ях яких не проживають психічно хворі пацієнти і які ніколи не звертались по допомогу до лікаря-психіатра.

У дослідженні використовували анамнестичний, соціально-демографічний, клініко-психологічний, психодіагностичний та статистичний методи.

Ступінь навантаження на сім'ю оцінювали за допомогою шкали оцінювання навантаження на сім'ю (Experience of Caregiving Inventory - ECI) [2], розробленої G. Szmukler et al. (1994). Шкала складається з 66 питань, згрупованих у 10 блоків, своєю чергою розподілених на дві субшкали: негативних і позитивних оцінок. За першою з цих субшкал оцінюють вісім основних конструктів: проблеми в поведінці; негативні симптоми; стигму; проблеми $з$ психіатричними закладами; вплив на сім'ю; необхідність підтримки хворого; залежність; збитки. Субшкала позитивних оцінок складається із двох конструктів: позитивний досвід і позитивні аспекти взаємин із хворим. При відповіді на те чи інше питання референтним родичам пацієнта пропонували на вибір один із п'яти варіантів відповіді: ніколи (0 балів), рідко (1 бал), іноді (2 бали), часто (3 бали), майже завжди (4 бали). При обробці отриманих даних підраховували суму балів за кожним розділом окремо. Результати оцінювали в динаміці у групах референтних родичів пацієнтів з ЕПР із тривалістю захворювання до 4 років (РРПШ1 і РРАФР1 відповідно), від 5 до 8 років (РРПШ2 і РРАФР2) та від 9 до 12 років (РРПШЗ і РРАФРЗ).

Рівень сімейної тривоги аналізували за опитувальником «Аналіз сімейної тривоги» Е.Г. Ейдеміллера та В. Юстіцкіса [9].

\section{Результати та їх обговорення}

Загалом, рівні сімейної тривоги в респондентів оцінювали за трьома базовими конструктами - сімейна провина, сімейна тривожність та сімейна напруженість (таблиия).

За субшкалою сімейної провини встановлені показники вказують на те, що референтні родичі пацієнтів із параноїдною шизофренією на відміну від респондентів РРАФР та КГ схильні переживати почуття провини за те, що відбувається в сім'ї, а також на тлі сімейної ситуації часто почуваються зайвими й непотрібними, переживають почуття незручності і власної неконгруентності. Показники за субшкалою сімейної тривожності вказують на те, що в референтних родичів, у сім'ях яких проживає пацієнт з ЕПР, значно зростає почуття власної безпорадності, безсилля, песимістичність при оцінюванні власних зусиль, хронічне переживання непередбачуваності та невизначеності сімейної ситуації загалом. Результати, отримані за субшкалою сімейної напруженості, свідчать про приховане почуття незадоволеності сімейною ситуацією, відчуття перевантаженості сімейними справами та обов'язками, переживаннями через сімейні справи, постійною необхідністю стримувати себе в ситуаціях інтерперсональної взаємодії в сім'ї. Результати, отримані за субшкалою композитного оцінювання, свідчать про те, що в референтних родичів пацієнтів 3 ЕПР загалом спостерігається занепокоєння сімейною ситуацією на тлі психічного розладу у близького члена сім'ї.

При вивченні динаміки показників соціальної тривоги в референтних родичів пацієнтів 3 ЕПР виявлено такі закономірності (puc. 1, 2). У референтних родичів пацієнтів із параноїдною шизофренією та афективними розладами високі рівні сімейної тривоги зберігаються при тривалості хвороби до 4 років та від 5 до 8 років, після чого показники сімейної тривоги знижуються до значень, які незначно відрізня-

Рівні сімейної тривоги референтних родичів пацієнтів з ЕПР, середній бал $(M \pm m)$

\begin{tabular}{l|c|c|c}
\hline \multicolumn{1}{c|}{ Показник } & \multicolumn{3}{|c}{ Група } \\
\cline { 2 - 4 } & КГ $(\mathrm{n}=55)$ & РРПШ $(\mathrm{n}=168)$ & РРАФР $(\mathrm{n}=75)$ \\
\hline Сімейна провина & $3,08 \pm 0,50$ & $4,21 \pm 0,50^{*}$ & $3,28 \pm 0,90$ \\
Сімейна тривожність & $2,18 \pm 0,10$ & $5,97 \pm 1,10$ & $5,14 \pm 1,60^{\#}$ \\
Сімейна напруженість & $2,13 \pm 0,70$ & $6,81 \pm 0,70^{\#}$ & $5,18 \pm 1,10^{\#}$ \\
Композитне оцінювання & $8,19 \pm 0,90$ & $16,10 \pm 1,70^{\#}$ & $13,72 \pm 1,50^{\#}$ \\
\hline
\end{tabular}

Примітка. Показники є статистично достовірними: * ${ }^{*}<0,05$; ${ }^{*} \mathrm{p}<0,001$. 
ються від даних КГ. Це, імовірно, вказує на поступове дистанціювання від актуальної сімейної ситуації з переключенням на інші сфери життя.

Рівень сімейної тривоги і психоемоційний стан референтних родичів пацієнтів з ЕПР загалом впливають на формування певного типу суб' єктивного ставлення до психічно хворого члена сім'ї, що, своєю чергою, визначає готовність сім'ї до участі в лікувально-реабілітаційному процесі, а також ресурс сімейної підтримки пацієнта.

За показниками шкали ЕСI в динаміці були проаналізовані зміни сімейного навантаження, що відбуваються в процесі захворювання (рис. 3, 4).

Загалом, динаміка середніх показників навантаження на сім'ю характеризується одночасним збільшенням показників за одними параметрами та зменшенням - за іншими зі збільшенням тривалості захворювання у психічно хворого члена сім'ї. За більшістю конструктів субшкали негативної оцінки сімейного навантаження (перші вісім конструктів) показники мають тенденцію до зростання в респондентів - РРПШ, тоді як у респондентів РРАФР спостерігаються поступова стабілізація і зниження показників сімейного навантаження. Виключенням $€$ показники за конструктом «проблеми з психіатричними закладами», які загалом знижувались як у групі РРПШ, так і в групі РРАФР, що можна пов'язати 3 набуттям референтними родичами досвіду звернення по спеціалізовану допомогу до відповідних лікувальних закладів.

Помітне збільшення рівня навантаження на сім'ю зі збільшенням тривалості захворювання відмічається за конструктами: «проблеми в поведінці», «стигма», «вплив на сім'ю», «збитки» (puc. 1, 2). При цьому загалом у респондентів - РРАФР мають місце нижчі показники, ніж у респондентів - РРПШ, що, імовірно, пов'язано з відмінностями в динаміці захворювань та симптоматики. У респондентів - РРПШ додатково спостерігається підвищення показників за розділами «негативні симптоми» та «підтримка хворого».

Вартий уваги той факт, що за субшкалою позитивних оцінок навантаження на сім'ю не виявлено суттєвих відмінностей залежно від тривалості захворювання між респондентами груп РРПШ та РРАФР.

Проведено якісний аналіз отриманих даних та встановлено суб'єктивне сприймання референтними родичами психічно хворого члена сім'ї як непередбачуваного, нерозважливого, підозрілого, дивного на вигляд та в поведінці за конструктом «проблеми в поведінці». У респондентів групи РРПШ високі

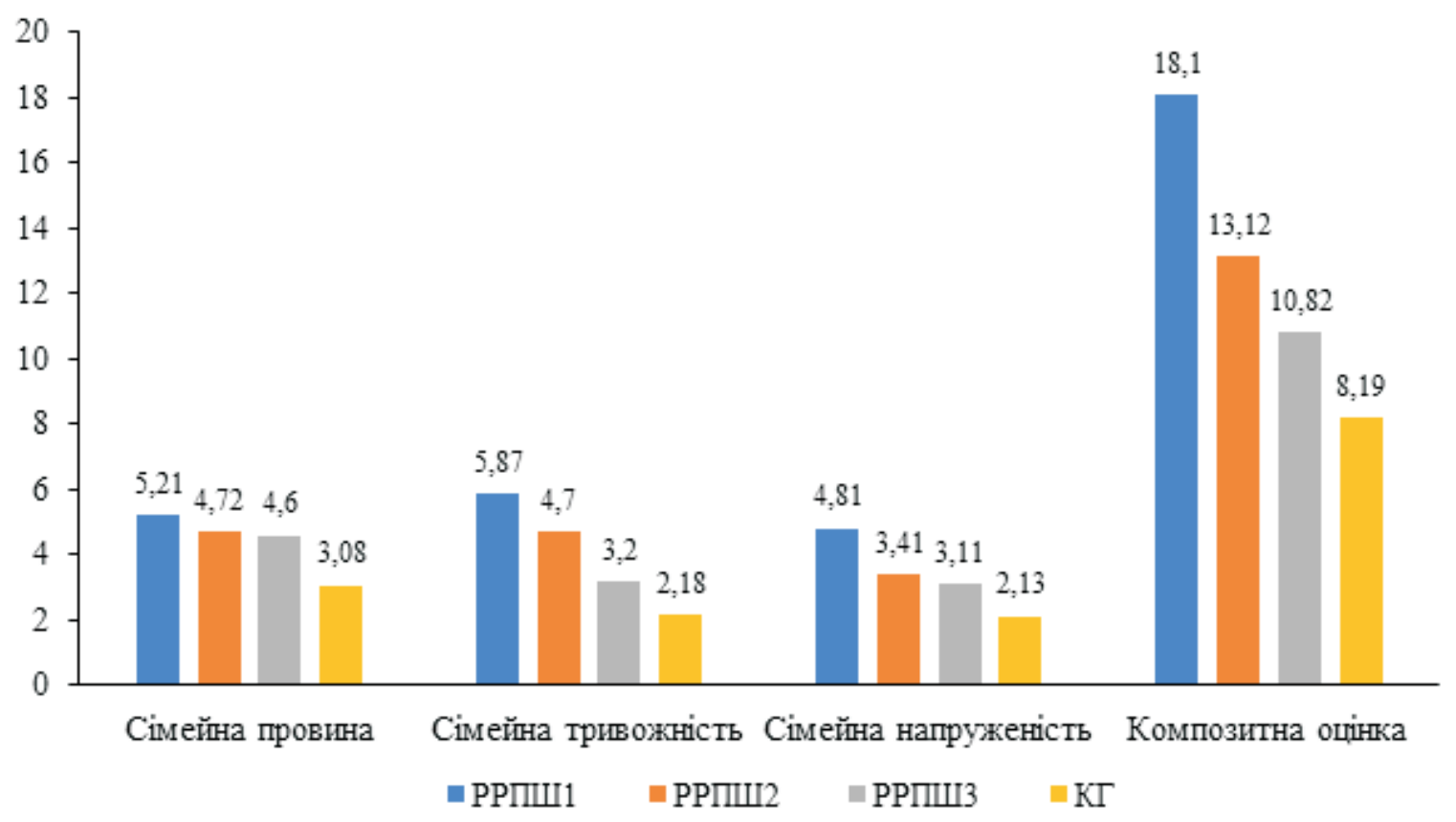

Рис. 1. Рівень сімейної тривоги референтних родичів пацієнтів із параноїдною шизофренією залежно від тривалості захворювання 


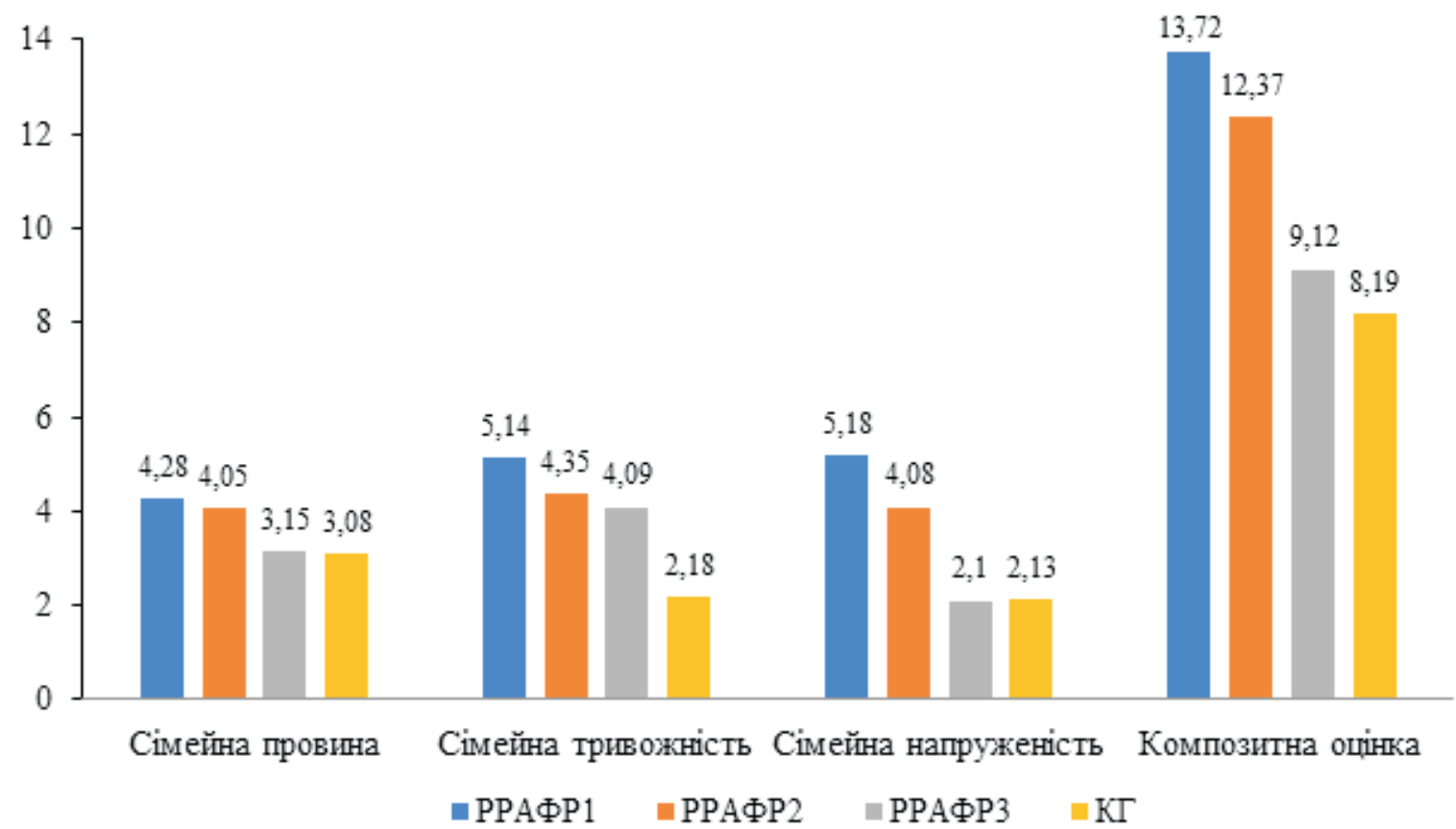

Рис. 2. Рівень сімейної тривоги референтних родичів пацієнтів 3 афективними розладами залежно від тривалості захворювання

показники за параметром «негативні симптоми» указують на схильність референтного родича оцінювати психічно хворого члена сім'і як схильного до усамітнення, нетовариського, незацікавленого, повільного, безвідповідального або нерішучого, що пояснюється настанням особистісних змін пацієнта та відображає нерозуміння референтними родичами

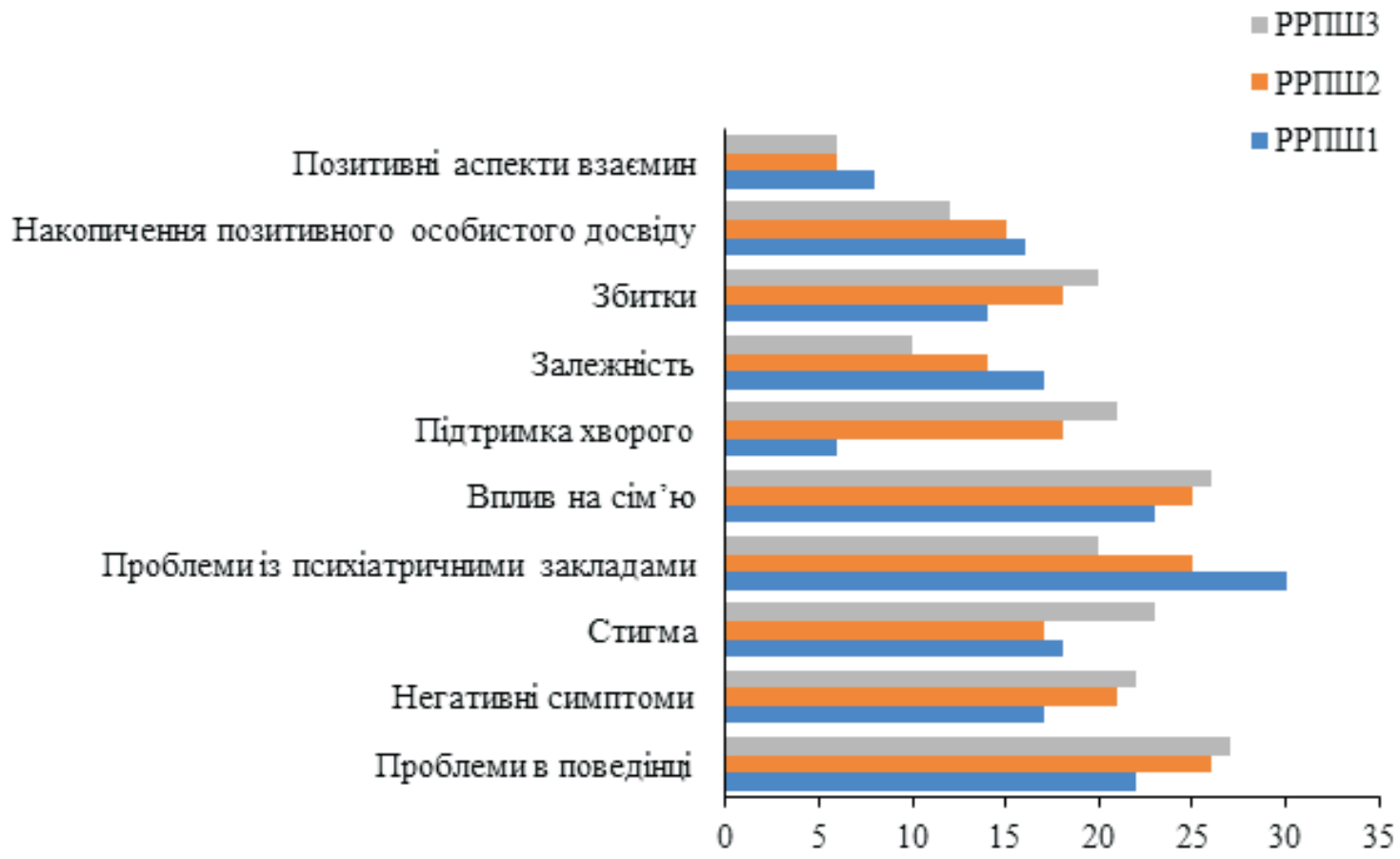

Рис. 3. Рівень сімейного навантаження на референтних родичів пацієнтів 3 параноїдною шизофренією залежно від тривалості захворювання 


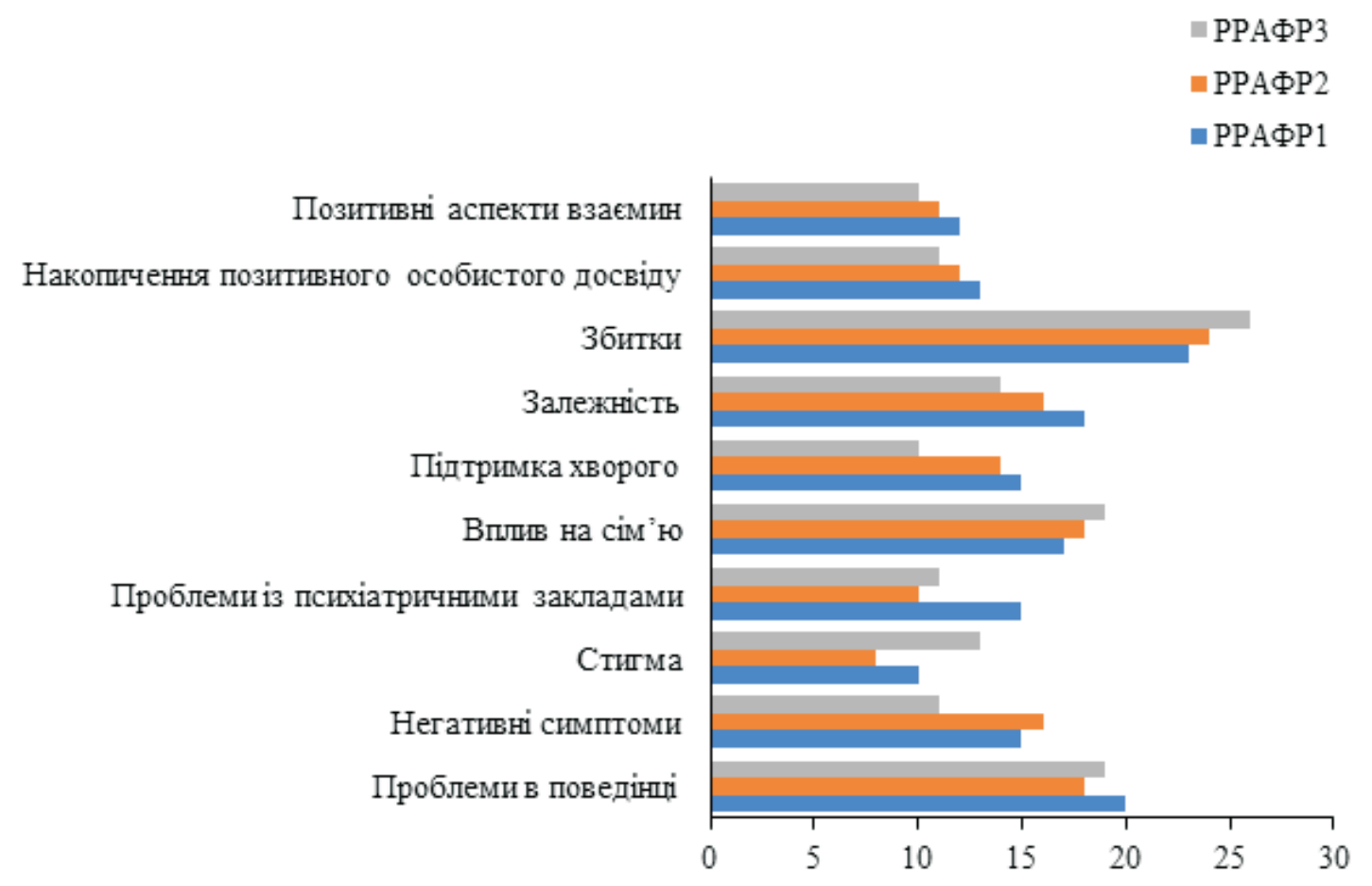

Рис. 4. Рівень сімейного навантаження на референтних родичів пацієнтів з афективними розладами залежно від тривалості захворювання

зв'язку цих змін із наявністю психічного захворювання.

Показники за конструктом «стигма» демонструють прагнення референтного родича приховувати захворювання члена сім’ї; нездатність розповісти кому-небудь про наявність у члена сім'ї психічного захворювання; пов'язане 3 цим уникання соціальних контактів; незнання, як пояснювати симптоми іншим; почуття сорому через наявність психічно хворого родича.

Конструкт «проблеми з установами, що обслуговують психічно хворих», указує на те, що, на думку референтного родича, співробітники, які обслуговують психічно хворих, не сприймають їх достатньо серйозно та не ставляться до проблеми їхнього родича 3 достатнім розумінням; а також на невміння викласти скарги 3 приводу догляду за хворим; труднощі щодо отримання інформації про його хвороби.

Конструкт «вплив на сім'ю» відображає зіткнення референтних родичів із нерозумінням із боку інших членів сім’і, розривом стосунків через небажання жити разом із хворим; негативним впливом психічного стану пацієнта на розвиток дітей; сприймання референтними родичами пацієнта як причини руйнування сім'ї, псування задоволення від сімейних подій та сімейного життя загалом.

За конструктом «підтримка хворого» з'ясовано, що респонденти як РРПШ, так і РРАФР оцінюють хворого члена сім'ї як такого, що не знає, як поводитись із грошима, через що їм доводиться забезпечувати або субсидувати його, коли в нього закінчуються гроші. Хвороба завдає удар по сімейному бюджету; референтному родичу доводиться забезпечувати пацієнта житлом; стежити, щоб він не зв'язався з поганою компанією.

За конструктом «залежність» показники $\epsilon$ трохи вищими в респондентів групи РРАФР, хоча мають тенденцію до поступового зниження. Цей розділ відображає нездатність референтних родичів робити те, що вони бажають через постійні тривожні думки про психічно хворого родича, якого сприймають як безпорадного і залежного, якому потрібно допомагати чимось заповнити свій день та якого референтні родичі остерігаються залишати самого в будинку.

Виражене зростання показників сімейного навантаження за розділом «збиток» в обох основних групах відображає роздуми референтних родичів про те, яке життя в них могло би бути; самозвинувачення та відчуття небезпеки, 
що пацієнт спробує скоїти самогубство; занепокоєння думками про смерть, утрачені можливості; побоювання, що пацієнт намагатиметься завдати собі шкоди; невіра в покращання його стану.

Конструкт «накопичення позитивного особистого досвіду», динаміка за яким є негативною в респондентів як групи РРПШ, так i групи РРАФР, відображає поступову втрату в них здатності до отримання позитивного досвіду сімейної взаємодії з пацієнтом, зокрема, використовувати таку взаємодію як спосіб більше дізнатись про себе, допомагати іншим зрозуміти, наскільки серйозно він хворий; отримання впевненості в собі шляхом спілкування з іншими людьми, розуміння проблем інших людей, зближення з друзями, нові знайомства, надбання гідності.

Так само виявлено поступове зниження показників у конструкті «позитивні аспекти взаємин», що вказує на схильність референтних родичів знецінювати свою роль у забезпеченні благополуччя психічно хворого члена сім'ї, а також заперечення здатності пацієнта бути корисним, демонструвати силу волі, намагаючись упоратись із хворобою; здат-ність до приємного спілкування; спільність інтересів.

Установлені особливості свідчать про те, що в розвитку ЕПР у члена сім'ї в референтних родичів поступово збільшується рівень сімейного навантаження за всіма конструктами, що зрештою може призводити до дистанціювання й уникання в ситуаціях внутрішньосімейної взаємодії.

\section{Висновки}

Прийняття хвороби сім'єю, усвідомлене та неупереджене ставлення до ії проявів у поєднанні з готовністю брати участь у забезпеченні психосоціальної реабілітації та реадаптації психічно хворого члена сім’ї-важливий фактор у лікуванні пацієнтів із ендогенними психічними розладами. У сім'ях хворих на ендогенні психічні розлади майже повсякчас існують проблеми усвідомлення та прийняття особистісних і поведінкових змін члена сім'ї, які $\epsilon$ наслідком проявів хвороби. Зазвичай у більшості референтних родичів спостерігається формальне прийняття хвороби. Недоцінюючи тяжкість ендогенних психічних розладів, референтні родичі висувають пацієнтам завищені вимоги, яким хворі з ендогенними психічними розладами не здатні відповідати. Така ситуація призводить до зростання конфліктності та дисфункціональності сімейної системи в цілому, появи комунікативних бар'єрів, наслідком чого може бути як екзацербація психічного розладу в пацієнта 3 ендогенним психічним розладом, так і загальне зниження якості життя всіх членів сім'ї.

Перспективою подальших досліджень $\epsilon$ врахування виявлених психосоціальних особливостей функціонування сім'ї, де проживає хворий, при розробці та впровадженні відповідної системи медико-психологічного супроводу для референтних родичів пацієнтів 3 ендогенними психічними розладами, спрямованої на підвищення соціально-терапевтичного потенціалу сім’і.

\section{Список літератури}

1. Бугорский $A$. В. Психиатрическое просвещение родственников пациентов, страдающих шизофренией и расстройствами шизофренического спектра / А. В. Бугорский // Психотерапия и психосоциальная работа в психиатрии / [под ред. О. В. Лиманкина, С. М. Бабина]. - СПб. : Таро, 2017. Вып. IV. - C. 49-56.

2. Гурович И. Я. Практикум по психосоциальному лечению и психосоциальной реабилитации психически больных / И. Я. Гурович, А. Б. Шмуклер, Л. И. Сальникова. - М. : Медиа-практика, 2002. - $180 \mathrm{c}$.

3. Caregiver burden and health in bipolar disorder: a cluster analytic approach / D. A. Perlick, R. A. Rosenheck, D. J. Miklowitz [et al.] // The Journal of Nervous and Mental Disease. - 2008. - Vol. 196 (6). P. 484-491.

4. Factors associated with the burden of family caregivers of patients with mental disorders: a crosssectional study / A. L. R. Souza, R. A. Guimaraes, D. de Araujo Vilela [et al.] // BMC Psychiatry. - 2017. Vol. 17 (1). - P. 353. - DOI : 10.1186/s12888-017-1501-1.

5. Zendjidjian $X$. Y. Challenges in measuring outcomes for caregivers of people with mental health problems / X. Y. Zendjidjian, L. Boyer // Dialogues Clin. Neurosci. - 2014. - Vol. 16 (2). - P. 159-169. 
6. Assessing health status in informal schizophrenia caregivers compared with health status in noncaregivers and caregivers of other conditions / S. Gupta, G. Isherwood, K. Jones, K. Van Impe // BMC Psychiatry. - 2015. - № 15. - DOI : 10.1186/s12888-015-0547-1.

7. Do needs, symptoms or disability of outpatients with schizophrenia influence family burden? / S. Ochoa, M. Vilaplana, J. M. Haro [et al.] // Social Psychiatry and Psychiatric Epidemiology. - 2008. Vol. 43 (8). - P. 612-618.

8. Assessment of the burden on caregivers of patients with mental disorders in Jeddah, Saudi Arabia / S. H. Alzahrani, E. O. Fallata, M. A. Alabdulwahab [et al.] // BMC Psychiatry. - 2017. - Vol. 17 (1). P. 202. - DOI : 10.1186/s12888-017-1368-1.

9. Awad A. G. The burden of schizophrenia on caregivers: a review / A. G. Awad, L. N. Voruganti // Pharmacoeconomics. - 2008. - № 26 (2). - P. 149-162.

10. Эйдемиллер Э. Г. Психология и психотерапия семьи / Э. Г. Эйдемиллер, В. Юстицкис. СПб., 1999. - С. 38, 555-556.

11. Evaluation of the acceptability and usefulness of an information website for caregivers of people with bipolar disorder / L. Berk, M. Berk, S. Dodd [et al.] // BMC Medicine. - 2013. - № 11 (1). - P. 162.

12. The psychosocial treatment of schizophrenia: an update / J. Bustillo, J. Lauriello, W. Horan, S. Keith // The American Journal of Psychiatry. - 2001. - № 158 (2). - P. 163-175.

13. Burden of care on caregivers of schizophrenia patients: a correlation to personality and coping / D. Geriani, K. S. Savithry, S. Shivakumar [et al.] // Journal of Clinical and Diagnostic Research. - 2015. № 9 (3). - VC01-VC04. - DOI : 10.7860/JCDR/2015/11342.5654.

\section{References}

1. Buhorskii A.V. (2017). Psikhiatricheskoie prosveshcheniie rodstvennikov patsiientov, stradaiushchikh shyzofreniiei i rasstroistvami shyzofrenicheskoho spektra [Psychiatric education for relatives of patients with schizophrenia and schizophrenic spectrum disorders]. Psikhoterapiia i psikhosotsialnaia rabota $v$ psikhiatrii - Psychotherapy and psychosocial work in psychiatry. O.V. Limankin, S.M. Babin (Ed.). $\mathrm{SPb}$.: Taro, issue IV, pp. 49-56 [in Russian].

2. Hurovich I.Ya., Shmukler A.B., Salnikova L.I. (2002). Praktikum po psikhosotsialnomu lecheniiu i psikhosotsialnoi reabilitatsii psikhicheski bolnykh [Guide for psychosocial treatment and psychosocial rehabilitation of the mentally ill patients]. Moscow: Media-praktika, 180 p. [in Russian].

3. Perlick D.A., Rosenheck R.A., Miklowitz D.J., Kaczynski R., Link B., Ketter T. et al. (2008). Caregiver burden and health in bipolar disorder: a cluster analytic approach. The Journal of Nervous and Mental Disease, vol. 196 (6), pp. 484-491.

4. Souza A.L.R., Guimaraes R.A., de Araujo Vilela D., de Assis R.M., Oliveira L.M.A.C., Souza M.R., Nogueira M.R., Barbosa M.A. (2017). Factors associated with the burden of family caregivers of patients with mental disorders: a cross-sectional study. BMC Psychiatry, № 17 (1), pp. 353, DOI 10.1186/ s12888-017-1501-1.

5. Zendjidjian X.Y., Boyer L. (2014). Challenges in measuring outcomes for caregivers of people with mental health problems. Dialogues Clin. Neurosci., № 16 (2), pp. 159-169.

6. Gupta S., Isherwood G., Jones K., Van Impe K. (2015). Assessing health status in informal schizophrenia caregivers compared with health status in non-caregivers and caregivers of other conditions. BMC Psychiatry, № 15, DOI 10.1186/s12888-015-0547-1.

7. Ochoa S., Vilaplana M., Haro J.M., Villalta-Gil V., Martinez F., Negredo M.C. et al. (2008). Do needs, symptoms or disability of outpatients with schizophrenia influence family burden? Soc. Psychiatry and Psychiatric Epidemiol., vol. 43 (8), pp. 612-618.

8. Alzahrani S.H., Fallata E.O., Alabdulwahab M.A., Alsafi W.A., Bashawri J. (2017). Assessment of the burden on caregivers of patients with mental disorders in Jeddah, Saudi Arabia. BMC Psychiatry, № 17 (1), pp. 202, DOI 10.1186/s12888-017-1368-1.

9. Awad A.G., Voruganti L.N. (2008). The burden of schizophrenia on caregivers: a review. Pharmacoeconomics, № 26 (2), pp. 149-162.

10. Eidemiller E.H., Yustitskis V. (1999). Psikholohiia i psikhoterapiia semi [Family psychology and psychotherapy]. St. Peterburg, pp. 38, 555-556 [in Russian]. 
11. Berk L., Berk M., Dodd S., Kelly C., Cvetkovski S., Jorm A.F. (2013). Evaluation of the acceptability and usefulness of an information website for caregivers of people with bipolar disorder. BMC Medicine, № 11 (1), pp. 162.

12. Bustillo J., Lauriello J., Horan W., Keith S. (2001). The psychosocial treatment of schizophrenia: an update. The American Journal of Psychiatry, № 158 (2), pp. 163-175.

13. Geriani D., Savithry K.S., Shivakumar S., Kanchan T. (2015). Burden of care on caregivers of schizophrenia patients: a correlation to personality and coping. Journal of Clinical and Diagnostic Research, № 9 (3), VC01-VC04, DOI 10.7860/JCDR/2015/11342.5654.

\section{А.А. Каминская, Н.К. Агишева \\ ФАКТОРЫ ПСИХОСОЦИАЛЬНОГО РЕСУРСА И ИХ ЗНАЧЕНИЕ В ФУНКЦИОНИРОВАНИИ СЕМЬИ, ГДЕ ПРОЖИВАЕТ БОЛЬНОЙ С ЭНДОГЕННЫМ ПСИХИЧЕСКИМ РАССТРОЙСТВОМ}

Обследовано 168 референтных родственников пациентов с параноидной шизофренией и 75 референтных родственников пациентов с аффективными расстройствами (биполярным аффективным и рекуррентным депрессивным расстройствами), у которых определяли уровни семейной нагрузки и семейной тревоги в контексте психосоциального функционирования обследованных. Группу контроля составили 55 психически здоровых лиц. Степень нагрузки на семью оценивали с помощью шкалы оценки нагрузки на семью по G. Szmukler et al. (1994), уровень семейной тревоги - по опроснику «Анализ семейной тревоги» Е.Г. Эйдемиллера и В. Юстицкиса. Выявлено, что высокие уровни семейной тревоги у референтных родственников сохраняются при продолжительности болезни до 4 лет и от 5 до 8 лет, после чего показатели снижаются до значений, которые незначительно отличаются от данных контрольной группы. Это, вероятно, указывает на постепенное дистанцирование от актуальной семейной ситуации с переключением на другие сферы жизни. С увеличением продолжительности заболевания уровень семейной нагрузки возрастает по субшкалам негативных оценок с одновременным снижением по субшкалам положительных оценок, что отражает сосредоточенность членов семьи на негативных аспектах заболевания. Данные закономерности необходимо учитывать при разработке соответствующей комплексной системы медико-психологического сопровождения семей, где проживают пациенты с эндогенными психическими расстройствами.

Ключевые слова: семейная тревога, тип отномения к психическому заболеванию, психоэмоииональная сфера, референтные родственники, эндогенные психические расстройства.

\section{A.O. Kaminska, N.K. Agisheva FACTORS OF PSYCHOSOCIAL RESOURCE AND THEIR IMPORTANCE IN FUNCTIONING OF FAMILIES WHERE A PATIENT WITH ENDOGENOUS MENTAL DISORDER LIVES}

As in many countries, in Ukraine, family caregivers of mentally ill patients face a liability to which they are not usually prepared, that requires maximum involvement of personal adaptation resources of all family members and the activation of psychosocial resource of the family as a whole as an environment where a patient with endogenous mental illness lives, in order to ensure his re-socialization and rehabilitation. Family burden and family anxiety are factors that determine psychosocial resource of family and its potential in terms of providing optimal conditions for promoting psychosocial rehabilitation of patients with endogenous mental disorders. We examined 168 reference relatives of patients with paranoid schizophrenia and 75 reference relatives of patients with affective disorders (bipolar affective and recurrent depressive disorders), in which the levels of family stress and family anxiety were determined in the context of the psychosocial functioning of the subjects. The control group consisted of 55 mentally healthy individuals. The degree of family burden was assessed using a family burden rating scale according to G. Szmukler et al. (1994), the level of family anxiety was assessed according to the questionnaire «Analysis of family anxiety» E.G. Eidemiller and V. Justickis. It was revealed that high levels of family anxiety in reference relatives persist with a disease duration of up to 4 years and from 5 to 8 years, after which the indicators decrease to values that slightly differ from the control group. This probably indicates a gradual distance from the current family situation with a switch to other areas of life. With an increase in the duration of the disease, the level of family burden increases according to the subscales of negative assessments, while the decrease in the subscales of positive assessments, which reflects the focus of family members on the negative aspects of the disease. These patterns must be taken into account when developing an appropriate integrated system of medical and psychological support for families where patients with endogenous mental disorders live.

Keywords: family anxiety, type of attitude towards mental illness, psycho-emotional sphere, family caregivers, endogenous mental disorders.

Надійшла 15.01.19 


\section{Відомості про авторів}

Камінська Анна Олексї̈вна - кандидат медичних наук, доцент, доцент кафедри медичної психології і психіатрії з курсом післядипломної освіти Вінницького національного медичного університету ім. М.І. Пирогова.

Адреса: 21018, м. Вінниця, вул. Пирогова, 56, Вінницький національний медичний університет ім. М.І. Пирогова.

Тел.: +38(097)971-98-87.

E-mail:kamynskaanna@gmail.com.

ORCID: https://orcid.org/0000-0002-6288-5890.

Агімева Наїля Каїсівна - кандидат психологічних наук, доцент, доцент кафедри сексології, медичної психології, медичної і психологічної реабілітації Харківської медичної академії післядипломної освіти.

Адреса: 61176, м. Харків, вул. Амосова, 58, Харківська медична академія післядипломної освіти.

Тел.: +38(097)491-91-89.

E-mail: agisevanaila085@gmail.com.

ORCID: https://orcid.org/0000-0003-0332-8952. 